\title{
ANALISIS PPN MEMBANGUN SENDIRI UNTUK PENGUSAHA KENA PAJAK DI INDONESIA
}

\author{
Fany Inasius \\ Jurusan Akuntansi, Fakultas Ekonomi dan Bisnis, Universitas Bina Nusantara \\ Jln. K.H. Syahdan No.9, Palmerah, Jakarta Barat 11480
}

\begin{abstract}
Value-Added Tax (VAT) imposition on self build activity will be distinguished if it is provided by using contractor service. As the result, different VAT treatment on both transactions above has implication to whole company's profit. In fact, the implementation of this regulation was ineffective because Taxable Firm will easily run away from such disadvantageous regulation. This paper focuses on comparison between VAT imposition to Taxable Firm in the form of limited liability company for self build activity and equal treatment to building construction provided by contractor. In fact, from comparative and descriptive researches, it is found that equal treatment on VAT imposition for self construction by Taxable Firm will not reduce income tax earnings compared with using contractor service. On the contrary, VAT imposition for self build activity by Taxable Firm in the form of Limited Liability Company becomes ineffective. In the other sides, because VAT in by means of self build activity that can not be credited it has implication to inefficiency that in turn will not conducive to business climates.
\end{abstract}

Keywords: Value Added Tax, Self Build Activity, Contractor Service, Taxable Firm

\begin{abstract}
ABSTRAK
Pengenaan Pajak Pertambahan Nilai (PPN) atas kegiatan membangun sendiri dibedakan bila dilakukan dengan perolehan melalui jasa kontraktor. Akibat dari perbedaan perlakuan PPN atas kedua transaksi di atas berimplikasi pada keuntungan perusahaan secara keseluruhan. Fakatnya dalam pelaksanaanya peraturan ini menjadi tidak efektif disebabkan dengan mudahnya Pengusaha Kena Pajak menghindari hal yang kurang menguntungkan seperti pada pengenaan atas PPN membangun sendiri. Penulisan ini memfokuskan pada perbandingan bila pengenann atas PPN pada Pengusaha Kena Pajak berbentuk Perseroan Terbatas untuk kegiatan membangun sendiri diperlakukan sama dengan perolehan gedung melalui kontraktor. Dari penelitian yang dilakukan dengan metode penelitian secara komparatif dan deskriptif didapatkan hasil bahwa perlakuan yang sama atas pengenaan PPN membangun sendiri pada Pengusaha Kena Pajak tidak mengurangi penerimaan pajak penghasilan dibandingkan dengan menggunakan jasa kontraktor. Sebaliknya peraturan PPN membangun sendiri bagi Pengusaha Kena Pajak berbentuk Perseroan Terbatas menjadi tidak efektif. Disamping itu karena PPN masukkan bagi perolehan dengan cara membangun sendiri yang tidak dapat dikreditkan berimplikasi pada inefisiensi yang pada gilirannya tidak mendukung iklim dunia usaha yang kondusif.
\end{abstract}

Kata kunci: PPN membangun sendiri, jasa kontraktor, pengusaha kena pajak 


\section{PENDAHULUAN}

Perkembangan ekonomi global yang semakin kompetitif menuntut iklim investasi yang semakin kondusif untuk menarik investasi. Pajak, sebagai salah satu komponen yang menjadi pertimbangan dalam pengambilan keputusan investor, memerlukan perbaikan yang berorientasi pada mendukung berkembangnya dunia usaha dan pelaku usaha. Ini berarti system perpajakan yang business friendly dibutuhkan dalam menunjang iklim investasi yang kondusif yang pada gilirannya akan berdampak perkonomian secara nasional.

Sebagaimana dinyatakan oleh Adam Smith bahwa pemungutan pajak harus memperhatikan aspek keadilan maupun kepastian hukum maka dalam rangka perbaikan peraturan pajak pertimbanganpertimbangan seperti penggunaan konsep yang konsisten, pengurangan beban administrasi, memaksimalkan potensi pertumbuhan merupakan pokok pikiran yang seharusnya mendasari perubahan peraturan pajak dalam menunjang berkembangnya dunia usaha. Oleh karena itu PPN sebagai bagian dari penerimaan pajak pusat agar dalam pemungutannya mempertimbangkan aspekaspek yang dapat mengurangi distorsi serta dapat memaksimalkan netralitas dalam ekonomi.

Membangun sendiri sebagai salah satu objek PPN sebagaimana diatur dalam pasal 16 C UU PPN Tahun 2009 adalah PPN yang dikenakan atas perolehan gedung karena membangun sendiri yang dilakukan tidak dalam kegiatan usaha atau pekerjaan oleh Orang Pribadi atau Badan yang hasilnya digunakan sendiri atau pihak lain. Adapun batasan dan tatacara membangun sendiri diatur lebih lanjut dalam Peraturan Menteri Keungan Nomor 39/PMK.03/2010. Singkatnya kegiatan membangun sendiri akan dikenakan PPN kepada wajib pajak baik orang pribadi (OP) maupun Badan dengan luas bangunan $300 \mathrm{~m} 2$ atau lebih.

Bahwa pemungutan pajak harus mempertimbangkan aspek keadilan maka terkait dengan peraturan tentang Pajak Pertambahan Nilai membangun sendiri akan menimbulkan pertanyaan apakah peraturan tersebut cukup fair bagi bagi wajib pajak Pengusaha Kena Pajak Badan khususnya yang berbadan hukum Pereseroan Terbatas (PT) bila memilih opsi membangun sendiri gedung kantor dibandingkan membeli atau menggunakan jasa kontraktor? Pertanyaan selanjutnya adalah haruskah dilakukan pemisahan peraturan pemungutan PPN bagi Pengusaha Kena Pajak berbentuk PT bila perolehan bangunan dilakukan dengan cara membangun sendiri yakni tidak melalui penggunaan jasa kontraktor?

Studi ini lebih memfokuskan pada Subjek pajak badan dengan spesikasi Wajib Pajak berbadan hukum PT yang sudah menjadi Pengusaha Kena Pajak (PKP) dengan pertimbangan adanya pemisahan antara asset PT dan asset pemilik PT. Untuk pembatasan masalah, pembahasan tentang PKP Wajib Pajak Orang Pribadi dan WP badan yang berbadan hukum selain PT tidak menjadi fokus dari penelitian ini disamping definisi dan luas bangunan yang bisa menjadi objek penelitian lain.

Pembahasan tentang analisa PPN membangun sendiri untuk PT yang sudah menjadi PKP dibandingkan dengan penggunaan jasa kontraktor dimulai dengan mendiskusikan pemungutan PPN atas kegiatan membangun sendiri maupun dengan perolehan melalui jasa kontraktor. Selanjutnya dilakukan perbandingan bila perusahaan memilih opsi membangun sendiri atau menggunakan jasa kontraktor. Akhirnya dilakukan perbandingan opsi bila PPN masukkan dapat dikreditkan baik atas kegiatan membangun sendiri maupun dengan menggunakan jasa kontraktor.

\section{Analisa Pustaka}

Perkembangan value added tax (Pajak Pertambahan Nilai) berkembang pesat dan hampir setiap tahun sebuah negara yang belum menggunakan Pajak Pertmbahan Nilai mulai menerapkannya (Tait, 1998). Di Indonesia Undang-undang PPN nomor 8 tahun 1983 diberlakukan pertama kali pada 
tanggal 1 Juli 1984 sebagai pengganti Undang-Undang Pajak Penjualan yang sudah berlaku sejak tahun 1951.

Sesuai Undang-Undang Nomor 28 tahun 2007 tentang Ketentuan Umum dan Tatacara Perpajakan (UU KUP) maka badan didefinisikan sebagai sekumpulan orang dan/atau modal yang merupakan kesatuan baik yang melakukan usaha maupun yang tidak melakukan usaha yang meliputi perseroan terbatas, perseroan komanditer, perseroan lainnya, badan usaha milik Negara, atau badan usaha milik daerah dengan nama dan dalam bentuk apapun, firma, kongsi, koperasi, dana pension, persekutuan, perkumpulan, organisasi masa, organisasi social politik, atau organisasi lainnya, lembaga dan bentuk badan lainnya, termasuk kontrak investasi kolektif dan badan usaha tetap. Adapun Pengusaha Kena Pajak sesuai pasal 1 ayat (5) UU KUP adalah Pengusaha yang melakukan penyerahan barang kena pajak dan/atau penyerahan jasa kena pajak yang dikenai pajak berdasarkan undangundang PPN. Dengan demikian dapat disimpulkan bahwa tidak semua badan termasuk perseroan terbatas adalah PKP.

Adapun pengenaan PPN atas kegiatan membangun sendiri yang dilakukan tidak dalam kegiatan usaha atau pekerjaan oleh orang pribadi atau badan yang hasilnya digunakan sendiri atau digunakan pihak lain yang batasan dan tatacaranya diatur dengan keputusan Menteri Keuangan sesuai pasal 16B UU PPN. Ini berarti perlakuan atas PPN membangun sendiri tidak membedakan apakah pembangunan gedung tersebut untuk kepentingan orang pribadi atau untuk tujuan perusahaan.

Sesuai Peraturan Menteri Keuangan nomor 39/PMK.03/2010 sebagai ketentuan pelaksana pasal 16B Undang-Undang PPN menguraikan bahwa suatu kegiatan membangun sendiri dikenakan PPN apabila tidak dilakukan dalam kegiatan usaha, dengan luas 300 meter persegi atau lebih, bersifat permanen dengan konstruksi utamanya berupa kayu, beton, baja atau bahan sejenis serta diperuntukan untuk tempat tinggal atau temapat usaha. Dengan demikian dapat disimpulkan bahwa jenis usaha perusahaan yang membangun sendiri bukan kontraktor serta peraturan tidak membedakan apakah bangunan tersebut untuk tempat tinggal atau untuk tempat usaha.

Kegiatan membangun bangunan yang dilakukan dengan menggunakan jasa kontraktor bukan merupakan kegiatan membangun sendiri sepanjang dapat dibuktikan bahwa telah dipungut PPN atas kegiatan tersebut (Sukardi, 2010).

Untuk penyusutan atas gedung permanen dilakukan dalam bagian yang sama besar selama 20 tahun sebagaimana diatur dalam pasal 11 UU Pajak Penghasilan. Ini berarti penyusutan atas perolehan gedung adalah sebesar 5\% pertahun. Selanjutnya berdasarkan UU Pajak Penghasilan maka Badan atau pembayar penghasilan kepada wajib pajak orang pribadi wajib memotong PPh pasal 21 yang diatur dalam Peraturan Menteri Keuangan nomor 252/PMK.03/2008 sebagaimana di atur lebih lanjut dalam PER-31/PJ/2009. Untuk pemotongan jasa kontraktor sesuai pasal 4 ayat (2) Undang-Undang Pajak Penghasilan dikenakan pajak yang bersifat final yang besarnya adalah 3\% untuk kontraktor berskala besar sesuai Peraturan Pemerintah nomor 40 Tahun 2009. Dengan demikian dapat disimpulkan bahwa pembayar penghasilan wajib memotong PPh sesuai jenis pembayaran yang dilkakukan.

Selanjutnya dalam menghitung jumlah penerimaan yang bersifat future cash flow maka penentuan present value menjadi relevan. Adapun present value merupakan future cash flow yang akan datang diperhitungkan dengan tingkat suku bunga yang wajar (Ross, Westerfield \& Jaffe, 2005)

\section{METODE}

Metode yang digunakan dalam pelaksanaan penelitian adalah metode penelitian komparatif, deskriptif dan wawancara. Penelitian komparatif dilakukan dengan melakukan penyelidikan dan pemahaman terhadap peraturan perpajakan yang telah berlaku dikaitkan dengan reaksi subyek 
penelitian dengan pengumpulan data yang berasal dari peraturan perpajakan dan wawancara terhadap wajib pajak. Adapun penelitian deskriptif dilakukan dengan melakukan penilaian sikap atas perturan yang telah ada. Berdasarkan analisa literatur dan observasi terhadap data-data yang diperoleh dibuat perbandingan yang dapat memberikan gambaran untuk menjawab pertanyaan mengenai tujuan penelitian.

\section{HASIL DAN PEMBAHASAN}

\section{Pemungutan PPN Membangun Sendiri}

Sesuai dengan pasal 16C UU PPN maka kegiatan membangun sendiri dikenakan PPN yang batasan dan tatacaranya diatur dengan Keputusan Menteri Keuangan. Selanjutnya, dalam Peraturan Menteri Keuangan Nomor 39/PMK.03/2009 diatur antara lain bahwa kegiatan membangun sendiri adalah kegiatan membangun bangunan yang dilakukan tidak dalam kegiatan usaha atau pekerjaan oleh orang pribadi atau badan yang hasilnya digunakan sendiri atau oleh pihak lain. Adapun luas keseluruhan bangunan paling sedikit 300 meter persegi. Selanjutnya disebutkan bahwa bahwa PPN membangun sendiri adalah $10 \%$ dari dasar pengenaan pajak, dimana dasar pengenaan pajak adalah 40\% dari jumlah biaya yang dikeluarkan untuk membangun bangunan tidak termasuk harga perolehan tanah. Disebutkan juga bahwa PPN masukkan atas kegiatan membangun sendiri tidak dapat diklreditkan.

Untuk gambaran yang lebih jelas berikut contoh bila wajib pajak berbentuk PT yang sudah menjadi Pengusaha Kena Pajak memilih opsi membangun sendiri. PT X (PKP) sebuah perusahaan dealer otomotif yang merencanakan untuk memulai operasi perusahaan pada 1 Januari 2011 dengan membangun sendiri sebuah gedung seluas 2.000 meter persegi sebagai bangunan kantor utama. Adapun biaya-biaya yang direncanakan untuk dikeluarkan meliputi: (1) pembelian material 6,6 milyar rupiah (terdiri dari harga material sebesar 6 milyar rupiah dan PPN masukkan sebesar 600 juta rupiah); (2) pembayaran tenaga kerja dan coordinator bangunan sebesar 3 juta rupiah (terdiri dari upah karyawan dan biaya penangung jawab proyek serta PPh pasal 21).

Tabel 1 Biaya Membangun sendiri

\begin{tabular}{lr}
\hline Biaya material & $6,000,000,000$ \\
PPN & $600,000,000$ \\
Total material & $6,600,000,000$ \\
Biaya tenaga kerja & $3,000,000,000$ \\
Total biaya gedung & $9,600,000,000$ \\
Penyusutan setahun membangun sendiri & $384,000,000$ \\
\hline Total Harga Gedung & $9,984,000,000$ \\
\hline
\end{tabular}

Berdasarkan total perhitungan dalam Tabel 1 maka PPN membangun sendiri yang harus dibayar adalah sebesar Rp 9.600.000.000 x 40\% x 10\% = Rp 384.000.000,- atau dengan kata lain PPN membangun sendiri sebesar $4 \%$ dari total bahan dan tenaga kerja. Ini berarti terjadi double tax untuk material karena pada saat pembelian telah dikenakan pajak pertambahan nilai.

Dari perhitungan di atas dapat disimpulkan bahwa total asset gedung adalah sebesar Rp9.984.000.000 (Sembilan milyar Sembilan ratus delapan puluh empat juta rupiah) yang terdiri dari 
bahan dan biaya tenaga kerja ditambah PPN masukkan. Adapun semua PPN masukkan sebesar Rp 984.000.000,- tidak dapat dikreditkan sesuai Peraturan Menteri Keuangan Nomor 39/PMK.03/2010.

\section{Penggunaan Jasa Kontraktor}

Melanjutkan contoh di atas bila PT X merencanakan menggunakan jasa kontraktor dalam membangun gedung kantor dengan asumsi telah memiliki tanah sendiri. Maka, asumsi yang digunakan adalah baik tenaga kerja maupun material disediakan oleh kontraktor dengan komposisi 31\% untuk tenaga kerja dan 69\% untuk material dengan harga sesuai market price yakni dalam biaya tenaga kerja sudah termasuk keuntungan kontraktor namun belum termasuk PPh pasal 4 ayat (2) yang harus ditanggung oleh kontraktor dengan perhitungan seperti pada Tabel 2.

Tabel 2 Menngunakan Jasa Kontraktor

\begin{tabular}{lr}
\hline Bahan Bangunan & $6,000,000,000$ \\
Tenaga kerja & $3,000,000,000$ \\
PPh pasal 4 (2) & $270,000,000$ \\
Harga Jual sebelum PPN & $9,270,000,000$ \\
PPN Keluaran & $927,000,000$ \\
Harga Jual & $10,197,000,000$ \\
\hline
\end{tabular}

Total pengeluaran kas yang dilakukan oleh PT X adalah sebesar Rp 10.197.000.000 dengan PPN yang dapat dikreditkan sebesar Rp 927.000.000. Ini berarti total biaya yang merupakan harga perolehan bangunan bagi PT X adalah sebesar Rp 9.270.000.000 (sembilan milyar dua ratus tujuh pulu juta rupiah).

\section{Perbandingan PPN dan Pajak Penghasilan}

Perbandingan antara membangun sendiri dan menggunakan jasa kontraktor dapat dilihat dari dua sisi yakni dari segi harga perolehan maupun dari segi Pajak yang harus dibayar.

Pertama bila dilihat dari segi harga perolehan maka terlihat bahwa dengan membangun sendiri harga perolehan gedung lebih tinggi dibandingkan bila menggunakan jasa kontraktor. Hal ini disebabkan seluruh PPN masukkan atas material (dengan asumsi semua material dikenakan PPN) tidak dapat dikreditkan disamping tambahan PPN atas kegiatan membangun sendiri sebesar $4 \%$ dari seluruh biaya yang dikeluarkan untuk membangun bangunan sebagaimana diatur dalam UU Pajak Pertambahan Nilai. Dengan demikian dapat disimpulkan bahwa kegiatan membangun sendiri tidak menguntungkan secara PPN dibandingkan menggunakan jasa kontraktor yang berarti ditinjau dari cara perolehan.

Kedua bila dilihat dari segi Pajak Penghasilan (PPh) terlihat bahwa akibat dari membangun sendiri jumlah PPh yang harus dibayar lebih kecil dibandingkan menggunakan jasa kontraktor. Dengan asumsi total peredaran bruto perusahaan di atas 50 milyar pertahun maka perbandingannya seperti pada Tabel 3. 
Tabel 3 Penghematan PPh

\begin{tabular}{lc}
\hline Penyusutan setahun membangun sendiri & $99,200,000$ \\
Penyusutan setahun menggunakan kontraktor & $463,500,000$ \\
Tambahan biaya karena membangun sendiri & $35,700,000$ \\
\hline Pengurangan PPh & $8,925,000$ \\
\hline
\end{tabular}

Secara keseluruhan perbandingan antara PPN dan PPh masih merugikan bila cara perolehan gedung adalah dengan membangun sendiri.

\section{Implikasi Perbedaan Perlakuan PPN}

Merujuk pada penjelasan perubahan ketiga UU PPN bahwa perubahan PPN antara lain bertujuan meningkatkan kepastian dan keadilan bagi pengenaan Pajak Pertambahan Nilai, menyederhanakan system Pajak Pertambahan Nilai, meningkatkan biaya kepatuhan serta mengurangi distorsi dan peningkatan kegiatan ekonomi.

Selanjutnya berdasarkan contoh perhitungan PPN atas kegiatan membangun sendiri dan pengenaan PPN bila menggunakan jasa kontrktor terlihat bahwa pengenaan PPN membangun sendiri untuk PKP yang berbentuk PT kurang efektif dan tidak menunjang kegiatan perekonomian.

Pertama dilihat apakah peraturan ini efektif atau tidak. Dalam dunia business yang serba kompetitif mengefisienkan biaya adalah hal yang mutlak dalam rangka mencapai tujuan perusahaan. Bagi perusahaan berbentuk PT yang sudah PKP dalam pengambilan keputusan business seperti perolehan gedung akan mempertimbangkan segala aspek yang dapat mengefisienkan biaya. Berdasarkan contoh tentang PT X di atas maka perusahaan akan memilih menggunakan jasa kontraktor. Mengapa demikian? Hal ini disebabkan bagi PT yang sudah PKP PPN masukkan atas gedung dapat dikredtkan sehingga membangun sendiri tanpa jasa kontraktor akan merugikan bagi perusahaan. Berdasarkan Peraturan Menteri Keuangan nomor 39/PMK.03/2010 perusahaan yang dikenakan PPN membangun sendiri adalah perusahaan yang usaha pokoknya bukan sebagai kontraktor. Ini berarti perusahaan yang membangun gedung di atas 300 meter persegi akan menggunakan jasa kontraktor mengingat bidang usaha pokok perusahaan yang membangun gedung bukan kontraktor. Persoalannya bila tidak melaporkan pembangunan gedung dengan menggunakan jasa kontraktor maka dikategorikan sebagai membangun sendiri. Bagi perusahaan baik perorangan maupun badan yang bukan PKP baik membangun sendiri maupun menggunakan jasa kontraktor tidak akan mendapat manfaat dari PPN masukkan yang diperoleh. Hal ini berbeda dengan PT yang PKP sehingga dapat memilih opsi yang efisien buat perusahaan. Ditinjau dari segi efektifitas pengenaan PPN membangun sendiri maka peraturan ini tidak efektif bagi PT yang sudah PKP karena perusahaan akan menggunakan jasa kontraktor. Bagi perusahaan berbentuk PT yang sudah PKP adalah tidak menguntungkan bila membangun sendiri gedung tanpa pengakuan adanya kontraktor karena hilangnya kesempatan mengkreditkan pajak masukkan. Dengan demikian bukankah peraturan tersebut menjadi kurang efektif karena perusahaan akan menghindari inefisiensi dengan membangun sendiri.

Kedua pengenaan PPN membangun sendiri tidak produktif dalam menunjang peningkatan kegiatan ekonomi. Hal ini disebabkan oleh factor hanya karena membangun sendiri (tidak menggunakan kontraktor) mengakibatkan perusahaan harus kehilangan hak untuk mengkreditkan pajak masukkan yang jumlahnya tergantung dari luas bangunan. Maka dapat disimpulkan bahwa factor penggunaan kontraktor menjadi penyebab dapat dikreditkannya PPN masukkan dibandingkan dengan membangun sendiri. 
Bila penggunaan kontraktor menjadi factor dikenakan tidaknya PPN membangun sendiri maka sepanjang membangun sendiri dapat memisahkan adanya kontraktor dan memungut pemotongan $\mathrm{PPh}$ pasal 4 ayat (2) maka kegiatan tersebut dapat dikategorikan sebagai bukan membangun sendiri. Ini berarti bagi perusahaan berbentuk PT yang sudah PKP bila tidak mengakui adanya jasa kontraktor maka semua aktivitas pembangunan dianggap membangun sendiri. Ditinjau dari segi penerimaan Negara dengan tidak menggunakan kontraktor maka ada kerugian penerimaan $\mathrm{PPh}$ atas jasa kontraktor yang tidak dilaporkan sehingga dikompensasikan dengan PPN membangun sendiri. Artinya, perusahaan tidak perlu mengakui adanya jasa kontraktor tetapi kegiatan tersebut dikategorikan sebagai membangun sendiri yang berarti PPN membangun sendiri maupun PPN masukkan atas material menjadi beban perusahaan. Faktanya sesuai dengan Undang-Undang PPN maka PPN masukkan atas perolehan gedung bangunan yang diperuntukkan dalam kegiatan usaha perusahaan dapat dikreditkan perusahaan. Ini berarti perusahaan harus memilih menggunakan jasa kontraktor dengan memotong PPh pasal 4 ayat (2) sebesar 3\% untuk kontraktor dengan ukuran pembangunan di atas Rp 1 milyar untuk dapat mengkreditkan PPN masukkan atau tidak memotong PPh atas jasa kontraktor dan kehilangan hak mengkreditkan PPN masukkan gedung tersebut

Bagi perusahaan secara umum memperoleh harga yang paling efisien menjadi sesuatu yang tidak dapat ditawar dikaitkan dengan tujuan perusahaan yaitu memaksimumkan nilai perusahaan. Dalam kaitan dengan kegiatan membangun gedung kantor adalah lebih efisien bila perusahaan ikut menngusahakan harga yang termurah dalam penentuan biaya pembangunan yang meliputi material dan tenaga kerja sehingga biaya perolehan gedung kantor dapat ditekan semaksimal mungkin. Ini berarti perusahaan yang efisien akan meminimalkan biaya perolehan semaksimal mungkin. Terkait dengan pembangunan gedung, bila perusahaan tidak melaporkan penggunaan kontraktor maka perusahaan harus mengakui adanya tenaga kerja yang berarti adanya $\mathrm{PPh}$ pasal 21. Oleh karena itu bila perusahaan menghindar pengakuan adanya kontraktor maka perusahaan harus membayar PPh pasal 21 yang besarnya bergantung pada jumlah gaji sesuai tarif PPh pasal 21 sebagaimana diatur dalam Peraturan Dirjen Pajak Nomor 31/PJ/2009 dan Peraturan Dirjen Pajak Nomor 57/PJ/2009.

\section{Perlakuan Pemungutan PPN yang sama atas Perolehan Gedung}

Perubahan Undang-Undang Pajak Penghasilan terbaru yakni Undang Undang Nomor 36 Tahun 2008 tentang Pajak Penghasilan telah mengatur secara jelas bahwa usaha jasa konstruksi adalah jasa yang dilakukan pemungutan pajak secara final. Adapun tarif jasa kontraktor untuk pelaksana pembangunan kategori usaha besar yang memiliki sertifikat adalah 3\% final dari total nilai kontrak jasa kontraktor yang dibayarkan sesuai dengan Peraturan Pemerintah Nomor 40 tahun 2009. Ditinjau dari sisi kontraktor maka penghasilan kontraktor dari usaha yang mengalami pemotongan PPh pasal 4 ayat (2) Undang-Undang Pajak Paenghasilan sudah tidak dilakukan penghitungan kembali PPh terhutang dalam rangka penghitungan pajak penghasilan dalam SPT Tahunan PPh kontraktor tersebut. Dengan demikian dapat disimpulkan bahwa secara fiscal penghasilan bersih sebelum pajak untuk jasa kontraktor skala besar bersertifikat adalah $12 \%$ dari total nilai kontrak yang diterima yang berlaku sejak tahun 2010.

Perubahan Undang-undang perpajakan baik UU Ketentuan Umum dan Tata Cara Perpajakan, Undang-Undang Pajak Penghasilan maupun Undang PPN dan PPn BM sejak tahun 2007 memberi angin segar bagi dunia usaha dengan peraturan yang lebih friendly dalam menunjang perekonomian nasional secara keseluruhan. Selaras dengan itu maka pengenaan PPN atas kegiatan membangun sendiri bagi PT yang sudah menjadi PKP dengan pengenaan PPN atas pembangunan gedung dengan menggunakan jasa kontraktor menjadi tidak relevan untuk dibedakan dalam mendorong pelaku usaha untuk tumbuh dengan efisien. Hal ini disebabkan dengan memberi kebebasan bagi perusahaan untuk memilih opsi apakah dengan membangun sendiri atau menggunakan jasa kontraktor untuk perolehan gedung akan mendorong efisiensi bagi dunia usaha dalam mengatur biaya yang harus dikeluarkan. Adapun pilihan yang dapat dilakukan perusahaan bila perlakuan PPN membangun sendiri tidak 
dibedakan dengan PPN atas perolehan gedung dengan menggunakan jasa kontraktor adalah sebagai berikut:

Pertama, bila perusahaan memilih untuk tidak menggunakan jasa kontraktor maka ini berarti perusahaan membangun sendiri. Untuk perusahaan yang tidak bergerak di bidang kontraktor membangun sendiri gedung dengan luas di atas 300 meter persegi membutuhkan tenaga ahli yang sekelas kontraktor sebagai coordinator lapangan. Dengan demikian dari segi efisiensi perusahaan memiliki kebebasan mengelola biaya sminimal mungkin. Ini berarti perusahaan akan mendapatkan harga yang termurah untuk pembelian bahan yang ada. Sebagai gambaran contoh PT X ditampilkan kembali dengan asumsi sebagai berikut:

Untuk total biaya tenaga kerja tenaga coordinator (memiliki NPWP) dibayarkan sejumlah $12 \%$ dari total pengeluran yakni Rp 1.080.000.000,- sisanya untuk pegawai harian coordinator tersebut sebanyak 30 orang senilai Rp 1.920.000.000,- maka perhitungan PPh pasal 21 koordinator proyek seperti pada Tabel 4.

Tabel 4 Perhitungan PPh Pasal 21

\begin{tabular}{cccr}
\hline Perhitungan PPh pasal 21 & & Tarif & \multicolumn{1}{c}{ PPh 21 } \\
\hline Dasar Pengenaan Pajak & $540,000,000$ & & \\
& $50,000,000$ & $5 \%$ & $2,500,000$ \\
& $200,000,000$ & $15 \%$ & $30,000,000$ \\
& $250,000,000$ & $25 \%$ & $62,500,000$ \\
& $40,000,000$ & $30 \%$ & $12,000,000$ \\
\hline PPh pasal 21 koordinator & & & $107,000,000$ \\
\hline
\end{tabular}

Berdasarkan perhitungan di atas sesuai Peraturan Dirjen Pajak Nomor 57/PJ/2009 terlihat bahwa PPh pasal 21 yang dipotong untuk coordinator pembangunan adalah sebesar Rp 107.000.000,Jumlah ini belum termasuk PPh pasal 21 yang harus dipotong bagi karyawan harian. Bila diasumsikan semua pegawai dikenakan tarif terendah dari PPh pasal 21 yakni sebesar 5\% maka total PPh pasal 21 adalah sebagai berikut:

Dengan asumsi semua pegawai telah berkeluarga maka PTKP setahun untuk masing-masing adalah Rp 15.960.000,- Dengan demikian maka total objek PPh pasal 21= Rp1.920.000.000 $\mathrm{Rp}(15.960 .000 \mathrm{X}$ 30) $=\mathrm{Rp} 1.441 .200 .000$,- maka $\mathrm{PPh}$ pasal $21=5 \%$ X Rp 1.441.200.000 $=$ Rp72.060.000,-

Ditinjau dari total penerimaan pajak untuk PPh pasal 21 maka jumlah ini bisa bervariasi dan bisa lebih besar tergantung pada komposisi material dan tenaga kerja serta jumlah yang diterima masing-masing pegawai. Semakin besar presentase tenaga kerja atas total biaya membangun sendiri maka semakin besar objek PPh pasal 21. Dengan demikian berdasarkan asumsi di atas maka minimal penerimaan Negara dari PPh pasal 21 yang adalah Rp 179.060.000 (Seratus tujuh puluh Sembilan juta enam puluh ribu rupiah). Disamping itu penerimaan Negara untuk PPh pasal 25 terjadi peningkatan sebesar Rp 12.300.000.- (Dua belas juta tiga ratus ribu rupiah) karena total penyusutan yang dilaporkan karena PPN masukkan boleh dikreditkan karena membangun sendiri lebih rendah sebesar Rp 49.200.000,- sebagaimana terlampir dalam Tabel 5. 
Tabel 5 Penghematan PPh Pasal 25

\begin{tabular}{lr}
\hline Harga gedung membangun sendiri & $9,984,000,000$ \\
Harga gedung menggunakan kontraktor & $9,000,000,000$ \\
Penyusutan membangun sendiri setahun & $499,200,000$ \\
Penyusutan menggunakan kontraktor setahun & $450,000,000$ \\
Pengurangan biaya karena membangun sendiri & $49,200,000$ \\
\hline Pengurangan PPh & $12,300,000$ \\
\hline
\end{tabular}

Ditinjau dari segi penerimaan Pajak Penghasilan maka total peningkatan penerimaan $\mathrm{PPh}$ pasal 25 selama 20 tahun adalah sebesar Rp 12.300 .000 × $20=\mathrm{Rp} 246.000 .000$,- Bila digunakan asumsi discount rate sebesar $10 \%$ untuk tahun 2011 maka total present value dari PPh pasal 25 adalah sebesar Rp 115.188.517,- Dengan demikian total penerimaan PPh adalah sebesar Rp 179.060.000 + Rp 115.188.517,- = Rp 294.248.517 (dua ratus sembilan puluh empat juta dua ratus empat puluh delapan ribu lima ratus tujuh belas rupiah).

Dari perhitungan di atas dapat disimpulkan bahwa dari segi penerimaan negara tidak terjadi penurunan Pajak penghasilan karena pemberian perlakuan yang sama atas PPN masukkan bagi Pengusaha Kena Pajak berbentuk PT untuk memilih opsi membangun sendiri.

Kedua bila PPN membangun sendiri dapat dikreditkan dan perusahaan memilih untuk tidak melaporkan jasa coordinator proyek yang berfungsi sebagai kontraktor. Misalkan untuk contoh PT X perusahaan hanya melaporkan total penggunaan tenaga kerja sebesar Rp 2 milyar sehingga total biaya perolehan gedung menjadi Rp 8.600.000.000, maka perhitungan kerugian perusahaan adalah seperti pada Tabel 6 berikut.

Tabel 6 Kerugian PPh Badan

\begin{tabular}{lr}
\hline Total material & $6,000,000,000$ \\
Total tenaga kerja & $2,000,000,000$ \\
Total harga perolehan gedung & $8,000,000,000$ \\
Total penyusutan & $400,000,000$ \\
Total penyusutan yang seharusnya & $450,000,000$ \\
kerugian penyusutan / tahun & $50,000,000$ \\
\hline PPh yang harus ditanggung & $12,500,000$ \\
\hline
\end{tabular}

Dari perhitungan dalam Tabel 6 diketahui bahwa bila perusahaan mengurangi jumlah biaya perolehan gedung sebesar Rp 1 milyar maka $\mathrm{PPh}$ pasal 25 yang harus dibayar perusahaan Rp 12.500.000 per tahun lebih besar dari seharusnya. Hal ini disebabkan total penyusutan secara fiscal seharusnya Rp 450.000 .000 (9.000.000.000:20) menjadi Rp 400.000.000 (8.000.000.000:20) yang berakibat meningkatnya laba perusahaan sebesar Rp 50.000.000 (lima puluh juta rupiah). Dengan demikian total PPh sebesar 25\% dari Rp 50.000.000, menjadi kerugian bagi perusahaan.

Di samping itu secara komposisi pembagian antara material dan tenaga kerja menjadi hal yang bisa menjadi pertanyaan mengingat adanya benchmark untuk usaha seperti jasa konstruksi. Bila dilihat tarif PPN membangun sendiri sebesar 4\% dapat disimpulkan bahwa secara perpajakan rationya adalah $40 \%$ buat tenaga kerja. Sehingga secara accounting report perusahaan terdapat kenaikan laba setiap 
tahun sebesar Rp 50 juta rupiah disamping ratio penggunaan tenaga kerja dan material yang penyimpangannya cukup signifikan. Bagi perusahaan yang mengutamakan efisiensi dan kelangsungan usaha alternatif ini menjadi tidak menarik dan berbahaya karena inefisiensi secara cash flow dan adanya penggelapan pajak.

\section{PENUTUP}

Berdasarkan hasil studi di atas dapat disimpulkan bahwa pemisahan pengenaan PPN masukkan atas kegiatan membangun sendiri dengan melalui kontraktor adalah tidak efektif dan efisien bagi Perusahaan berbentuk Perseroan Terbatas yang sudah menjadi Pengusaha Kena Pajak disamping unfairness dalam menunjang pertumbuhan dunia usaha di Indonesia. Bagi perusahaan berbetuk PT yang entitasnya terpisah dari pemiliknya akan mencari cara yang paling efisien dalam mencapai tujuan perusahaan. Dengan demikian bila membangun sendiri dikenakan PPN yang tidak dapat dikreditkan maka perusahaan akan mengalami kerugian dari PPN masukkan yang berimplikasi pada kenutungan perusahaan secara keseluruhan. Oleh karena itu perusahaan akan memilih menggunakan jasa kontraktor yang polanya adalah membangun sendiri sehingga semua PPN baik material maupun jasa kontraktor dapat dikreditkan. Sehingga dapat disimpulkan peraturan ini menjadi tidak efektif karena akan dihindari oleh perusahaan yang memahami peraturan ini. Disamping itu pengenaan PPN membangun sendiri pada PT menimbulkan inefisiensi bagi perusahaan karena harus menggunakan jasa kontraktor. Selanjutnya dari sisi penerimaan tidak terlihat pengurangan penerimaan PPh bila dilakukan perlakuan yang sama untuk pemungutan PPN.Namun studi ini memiliki keterbatasan dalam menghitung komposisi material dan tenaga kerja disamping struktur gaji yang terstandarsasi untuk penghitngan PPh pasal 21 bagi usaha yang bergerak di bidang kontraktor. Untuk itu diperlukan penelitian yang lebih lanjut untuk dalam menghitung komposisi bahan, Pajak penghasilan pasal 21 dan discount rate yang lebih akurat mengingat tingkat suku bunga, inflasi dan market risk yang selalu berubah dari tahun ke tahun.

\section{DAFTAR PUSTAKA}

Dirjen Pajak. (2009). Peraturan Dirjen Pajak nomor PER-31/PJ/2009 tentang pedoman teknis tatacara pemotongan, penyetoran dan pelaporan pajak penghasilan pasal 21 dan/atau pajak penghasilan pasal 26 sehubungan dengan pekerjaan, jasa, dan kegiatan orang pribadi. Berita Negara Republik Indonesia.

Dirjen Pajak. (2009). Peraturan Dirjen Pajak nomor PER-57/PJ/2009 tentang pedoman teknis tatacara pemotongan, penyetoran dan pelaporan pajak penghasilan pasal 21 dan/atau pajak penghasilan pasal 26 sehubungan dengan pekerjaan, jasa, dan kegiatan orang pribadi. Berita Negara Republik Indonesia.

Presiden Republik Indonesia. (2009). Peraturan Pemerintah nomor 40 tahun 2009 tentang pajak penghasilan atas penghasilan dari usaha jasa konstruksi. Lembar Negara Republik Indonesia Tahun 2009 Nomor 83.

Republik Indonesia. (2008). Undang-undang Nomor 36 tahun 2008 tentang Pajak Penghasilan. Lembar Negara Republik Indonesia Tahun 2008 Nomor 133. 
Republik Indonesia. (2009). Undang-undang nomor 42 tahun 2009 tentang Pajak Pertambahan Nilai barang dan jasa dan Pajak Penjualan atas Barang Mewah. Lembar Negara Republik Indonesia Tahun 2009 Nomor 150.

Republik Indonesia. (2007). Undang-undang Nomor 40 Tahun 2007 tentang Perseroan Terbatas. Lembar Negara Republik Indonesia Tahun 2007 Nomor 106.

Ross, S. A., Westerfield, R. W., \& Jaffe, J. F. (2005). Corporate Finance. Mc Graw-Hill.

Sukardi, U. (2010). Pokok-pokok Pajak Pertmbahan Nilai. Rajawali Pers.

Tait, A. A. (1988), Value added Tax: International practice \& problems. International Monetary Fund. 